\title{
NALAZ STRANE VRSTE Cinara (Cinara) cedri (HEMIPTERA; APHIDIDAE) U ISTRI, HRVATSKA
}

\author{
RECORD OF ALIEN Cinara (Cinara) cedri, \\ (HEMIPTERA; APHIDIDAE) IN ISTRIA, CROATIA
}

Nediljko LANDEKA ${ }^{1 *}$, Martina PODNAR ${ }^{2}$

\begin{abstract}
Sažetak
Lisna uš Cinara cedri strana vrsta hrvatske apidofaune, zabilježena je na području Pule (Istra, Hrvatska) na libanonskom cedru (Cedrus libani). Uz morfološku, provedena je i molekularna identifikacija vrste. Standardizirani fragment mitohondrijskog gena za podjedinicu I citokrom c oksidaze (tzv. DNA barkod regija) korišten je kao molekularni biljeg. Monitoringom u razdoblju od 2013. do 2015. godine nisu utvrđene populacije ove vrste na širem području niti povećana brojnost na istoj lokaciji.
\end{abstract}

KLJUČNE RIJEČI: Aphididae, Cinara cedri, Pula, Hrvatska, strana vrsta, DNA barkodiranje

\section{UVOD}

\section{INTRODUCTION}

Od 4700 vrsta lisnih uši (Hemiptera: Aphididae), koliko ih je otprilike poznato, jedna trećina živi na području Europe među kojima su i mnoge strane (Coeur d’acier i dr. 2010). Nedavni podaci za područje Hrvatske navode 14 vrsta (Matošević i Pajač Živković 2013). Iako rod Cinara čine 222 vrste i drugi je najbrojniji rod iz porodice Aphididae, veći dio čine vrste koje ne žive u Europi. Samo su tri vrste do sada zabilježene u Europi kao strane vrste, od kojih Cinara laportei (Remaudière, 1954) i Cinara cedri (Mimeur, 1936) dolaze iz Sjeverne Afrike, a Cinara curvipes (Patch, 1912) iz Sjeverne Amerike. Teško je utvrditi da li su vrste C. laportei i C. cedri pristigle s biljkom domaćinom koja se nasađuje na području Europe ili su možda došla vjetrom ili zračnim strujama, ali se zna da su ograničene na cedar, najčešće u parkovima i vrtovima (Coeur d'acier i dr. 2010). Za razliku od njih C. curvipes napada i druge vrste crnogorice, pa joj domaćin mogu biti i autohtone vrste (Abies, Picea, Tsuga, Pinus) (Scheurer i Binazzi 2004). Za vrstu C. cedri poznato je da je prisutna u Alžiru, Argentini, Belgiji, Danskoj, Engleskoj, Francuskoj, Mađarskoj, Izraelu, Italiji, Libanonu, Maroku, Srbiji, Crnoj Gori, Španjolskoj, Švedskoj, Siriji, Cipru i Kini (Aytar 2006; Yu i Wang 2014; Binazzi i dr. 2015). Napada vrste Cedrus atlantica (Endl.) Manetti ex Carr., Cedrus brevifolia Elwes et Henry, libanonski cedar, Cedrus libani A. Rich, Cedrus deodara Roxb. ex D. Don i Pinus sp. Živi u kompaktnim kolonijama na koju se naseljavaju gljivice čađavice, jer izlučuje slatku i ljepljivu mednu rosu. Tijekom velikog porasta brojnosti može izazvati i opadanje grančice cedra te uzrokovati štete na plantažama cedra, što je zabilježeno za područja južne Francuske (Fabre i dr. 1988) i Turske (Aytar 2006). Iako se vrsta C. cedri navodi na popisu stranih fitofagnih vrsta na drvenastom bilju u Hrvatskoj (Matošević i Pajač Živković 2013), daljnjim pregledom

\footnotetext{
1 Mr. sc. Nediljko Landeka, Zavod za javno zdravstvo Istarske županije, Public Health Institute of the Istrian Region, Nazorova 23, p.p.192, HR-52100 Pula, Hrvatska, ddd@zzjziz.hr

${ }^{2}$ Dr. sc. Martina Podnar, Hrvatski prirodoslovni muzej, Croatian Natural History Museum, Demetrova 1, HR-10000 Zagreb, Hrvatska, martina.podnar@hpm.hr Dopisni autor, Corresponding author
} 
referenci ne može se sa sigurnošću potvrditi tko ju je prvi put zabilježio i gdje na području Hrvatske (Fabre 1976; Coeur d'acier i dr. 2010).

U jesen 2012. godine Zavod za javno zdravstvo Istarske županije zaprimio je dojavu o neuobičajenoj masovnoj pojavnosti nepoznatih vrsta kukaca uočenih na zidovima višestambenog objekta, na terasama, ali i u unutrašnjim prostorima objekta nakon ulaza kroz otvorene prozore s grana libanonskog cedra. Preliminarni pregled materijala pokazao je da se najvjerojatnije radi o jednoj od vrsta biljnih ušiju iz roda Cinara.

Cilj ovog rada je precizno određivanje vrste biljne uši nađene u Istri na temelju analize morfoloških i molekularnih značajki.

\section{MATERIJALI I METODE MATERIALS AND METHODS}

Na poziv vlasnika objekta, u Puli, ul. P. Budicin br. 25., o pojavi neuobičajenih kukaca uzet je uzorak (slika 1.) te je materijal pregledan pod entomološkom lupom i fotografiran.

Uzorci uzeti tijekom prvog nalaza pregledani su entomološkom lupom u Zavodu za javno zdravstvo Istarske županije Olimpus SZX9 i fotografirani na lupi Olympus 5.0 i na 3D lupi Stereo-mikroskop Discovery V20, Zeiss Hrvatskog veterinarskog instituta, gdje su i precizno izmjereni (Slika 2.).

Budući da morfološka analiza nije bila u potpunosti sigurna (Blackman 2006, Poljaković-Pajnik 2002) napravljena je DNA analiza u laboratoriju Hrvatskog prirodoslovnog muzeja u Zagrebu.

Kroz 2013., 2014. i 2015. godinu proveden je povremeni monitoring na 10 libanonskih cedrova na području grada Pule (Ul. Pino Budicin k. br. 25. - 1 stablo, Ul. Pino Budicin k. br. 4. - 1 stablo, Ul. Pino Budicin k.br. 1. - 2 stabla, Mornarički park - 2 stabla, B. Kosa k. br. 16. - 1 stablo, park Montezaro - 2 stabla i Park pod Arenom - 1 stablo). Uz pregledavanje grana i kore debla uzeti su i uzorci zemlje i opalih iglica i pregledavani pod entomološkom lupom.

\section{Molekularna identifikacija - Molecular identification}

Ukupna genomska DNA izolirana je pojedinačno iz dvije jedinke korištenjem komercijalnog kompleta PureLink Genomic DNA Mini Kit (Invitrogen) i eluirana u $50 \mu$ l pufera za eluaciju.

Molekularno-genetička determinacija nepoznatih uzoraka provedena je metodom DNA barkodiranja usporedbom s ranije karakteriziranim vrstama roda Cinara i to na temelju filogenetske analize sekvenci dostupnih u banci gena (226 sekvenci, 56 vrsta, pristupni brojevi u banci gena: KF649338, KF649340, KF649342 - KF649355, KF649357 - KF649565 i KJ433268, Jousselin i dr. 2013; Yu i Wang
2014), kao i korištenjem analitičkih alata i sekvenci platforme BOLD (1265 sekvenci, 99 vrsta; Barcode of Life Database System, www.boldsystems.org).

Metodologija DNA barkodiranja predložena je 2003. godine kao univerzalni sustav za determinaciju biološkog materijala u smislu identifikacije vrste u svim razvojnim stadijima, ali također i kao oruđe za otkrivanje novih tzv. kriptičnih vrsta koje se ne mogu međusobno razlikovati na temelju morfoloških karakteristika (Hebert i dr. 2003). Pri tome se određuje slijed nukleotida standardiziranog fragmenta mitohondrijskog $(\mathrm{mt})$ gena za podjedinicu jedan citokrom c oksidaze (COI) dužine oko 650 pb tzv. DNA barkod regija.

$\mathrm{Za}$ obje jedinke, lančanom reakcijom polimeraze (PCR) umnožena je DNA barkod regija uporabom LCO1490: 5'-ggtcaacaaatcataaagatattgg-3' i HCO2198: 5'-taaacttcagggtgaccaaaaaatca-3' (Folmer i dr. 1994) PCR početnica. Reakcijska smjesa od $50 \mu \mathrm{l}$ sadržavala je pufer (Go Taq ${ }^{\circledR}$ Reaction Buffer, Promega), 1,5 $\mathrm{mM} \mathrm{MgCl}_{2}, 0,2 \mathrm{mM}$ svakog dNTP-a, $0,4 \mu \mathrm{M}$ obje početnice, $1,25 \mathrm{u}$ Taq polimeraze (Go Taq ${ }^{\circ}$ DNA Polymerase, Promega) te $4 \mu$ l eluata genomske DNA. Uvjeti PCR reakcije obuhvaćali su početnu denaturaciju od 2 min na $94^{\circ} \mathrm{C}$, zatim 35 ciklusa naizmjenične denaturacije $\left(94^{\circ} \mathrm{C} / 30 \mathrm{~s}\right)$, sparivanja $\left(50^{\circ} \mathrm{C} / 30 \mathrm{~s}\right) \mathrm{i}$ elongacije $\left(72^{\circ} \mathrm{C} / 1 \mathrm{~min} 30 \mathrm{~s}\right)$, nakon čega je slijedila završna elongacija na temperaturi od $72^{\circ} \mathrm{C}$ u trajanju od 7 minuta. Određivanje slijeda nukleotida provedeno je u servisu za sekvencioniranje (Macrogen Inc, Korea) uporabom LCO1490 (uzorak CINC1) i HCO2198 (uzorak CINC2) početnica.

Sekvence DNA barkod regije vrsta roda Cinara povučene iz banke gena sravnjene su s dvije sekvence iz ovog istraživanja uporabom opcije „ClustalW Multiple sequnce Alignment" u programu BioEdit v.7.1.3 (Hall 1999).

Genetičke udaljenosti izračunate su u računalnom programu MEGA (verzija 6, Tamura i dr. 2013) korištenjem K2P (Kimura two-parameter) evolucijskog modela. Ovaj evolucijski model uobičajeno se koristi za određivanje genetičkih udaljenosti u studijama barkodiranja (Coeur d'acier i dr. 2014) te je odabran da bi se mogli uspoređivati rezultati ovog i prijašnjih istraživanja.

Filogenetska analiza provedena je Bayesian metodom (3 000000 generacija uz uzorkovanje svake tisućite generacije te odbacivanje prvih $20 \%$ stabala) uz pomoć računalnog programa MrBayes (version 3.1.2, Ronquist i Huelsenbeck 2003). Evolucijski model koji najbolje odgovara setu podataka, TPM3uf $+\mathrm{I}+\mathrm{G}$, prethodno je odabran računalnim programom jModelTest 0.1.1 (Posada 2008) uporabom Bayesian informacijskog kriterija. COI sekvence vrsta Lachnus roboris, Trama troglodytes i Tuberolachnus salignus korištene su kao vanjska grupa (Jousselin i dr. 2013). 


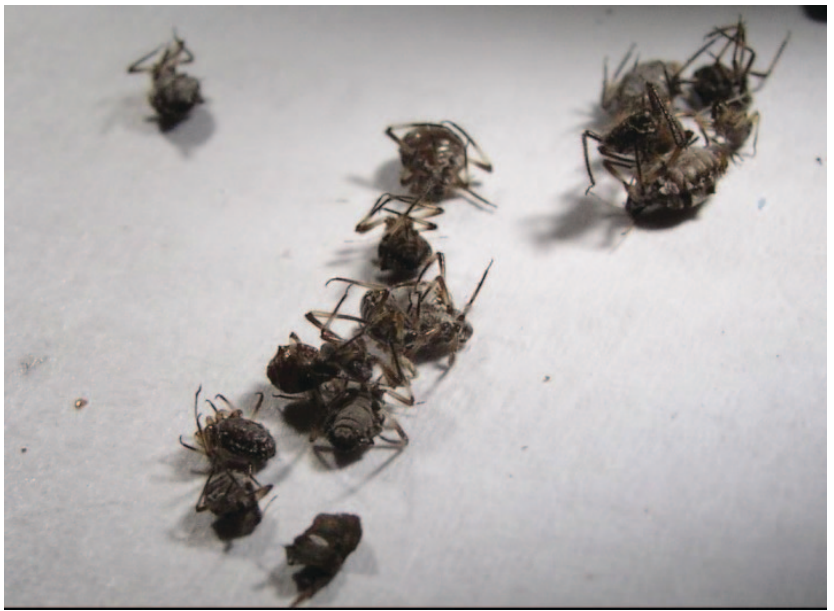

Slika 1. Uzorak Cinara cedri uzet 23. listopada 2012. godine Figure 1 Sample Cinara cedri taken on October 23rd, 2012

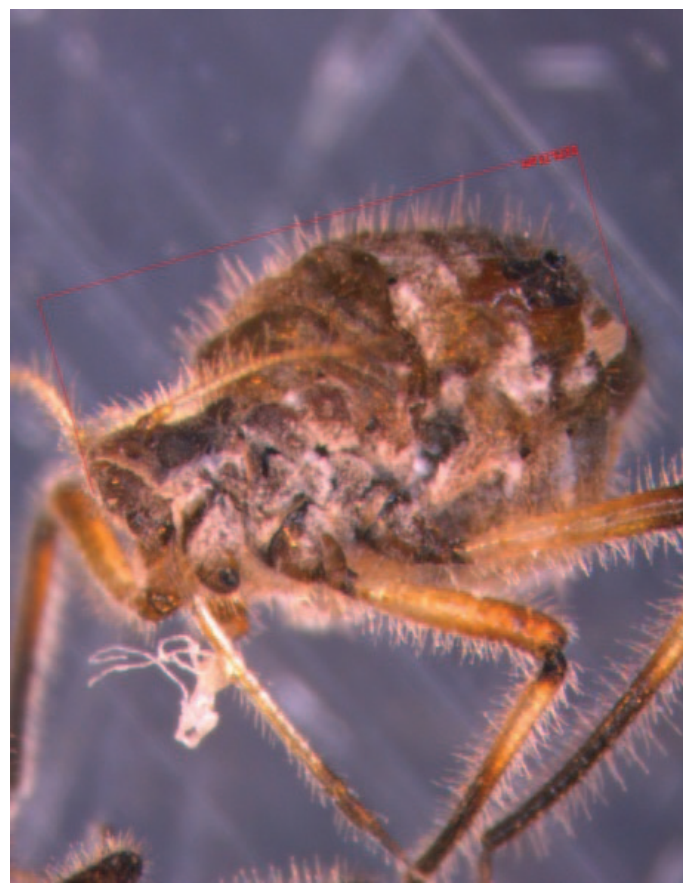

Slika 2. Imago Cinara cedri pod 3D lupom (foto R. Bek) Figure 2 Adult of Cinara cedri under 3D microscope (photo R. Bek)

\section{REZULTATI}

\section{RESULTS}

Rezultati ovog istraživanja pokazuju da je C. cedri i morfološki i analizom DNA utvrđena na jednom lokalitetu u Istri tijekom 2012. godine.

Daljnji monitoring proveden je na 10 libanonskih cedrova na kojima tijekom 2013., nisu utvrđene jedinke C. cedri. U uzorku zemlje i otpalih iglica ispod stabla 2014. godine na lokalitetu Ul. P. Budicina 25, pronađene su uginule jedinke C. cedri. U uzorku 2015. nisu pronađeni tragovi C. cedri, ali su pronađeni ostaci harlekinske božje ovčice, Harmonia axyridis (Pallas, 1773), invazivne vrste božje ovčice.
Sekvence dva uzorka iz Pule (CINC1, 650 pb i CINC2, 655 $\mathrm{pb}$ ) pohranjene su u Banci Gena (pristupni brojevi u Banci Gena: KU754491, KU754492) i međusobno su istovjertne u području preklapanja (647 pb). S rasponom udvojenih K2P genetičkih udaljenosti od 0,0 do 1,6 \%, uzorci iz Pule pokazali su se najsličniji vrsti C. cedri, dok su genetičke udaljenosti između njih i svih ostalih vrsta roda Cinara veće od $7,7 \%$. Štoviše, u području preklapanja (629 pb) sekvence uzoraka iz Hrvatske istovjetne su nedavno objavljenoj sekvenci uzorka iz Kine (Yu i Wang 2014).

Identifikacija putem BOLD platforme svrstala je oba uzorka iz Pule s 99,7 postotnom vjerojatnošću u vrstu C. cedri.

Rezultati filogenetske analize prikazani su na slici 4. Uzorci iz Pule grupiraju se s visokom podržanošću (posteriorna vjerojatnost, $\mathrm{BPP}=1,00$ ) unutar monofiletske grupe koja obuhvaća sve do sada analizirane uzorke vrste C. cedri (slika 4 b.). Unutar te Cinara cedri grupe, dobro su podržane dvije podgrupe od kojih jedna obuhvaća uzorke iz Italije, Francuske i SAD (K2P genetičke udaljenosti: 0,0-0,3\%.), a druga uzorke iz Pule i kineski uzorak (K2P genetička udaljenost: $0,0 \%)$. Udvojene K2P genetičke udaljenosti između dvije podgrupe su u rasponu od 1,4 do $1,6 \%$.

\section{RASPRAVA} DISCUSSION

Pronalaskom nove strane vrste štetnika na libanonskom cedru na području Pule 23. listopada 2012. godine otvara se pitanje njene prisutnosti i u ostalim dijelovima Hrvatske. Praćenjem cedrova u blizini mjesta nalaza, u gradu Puli, nije utvrđena prisutnost na drugim stablima do jeseni 2015.

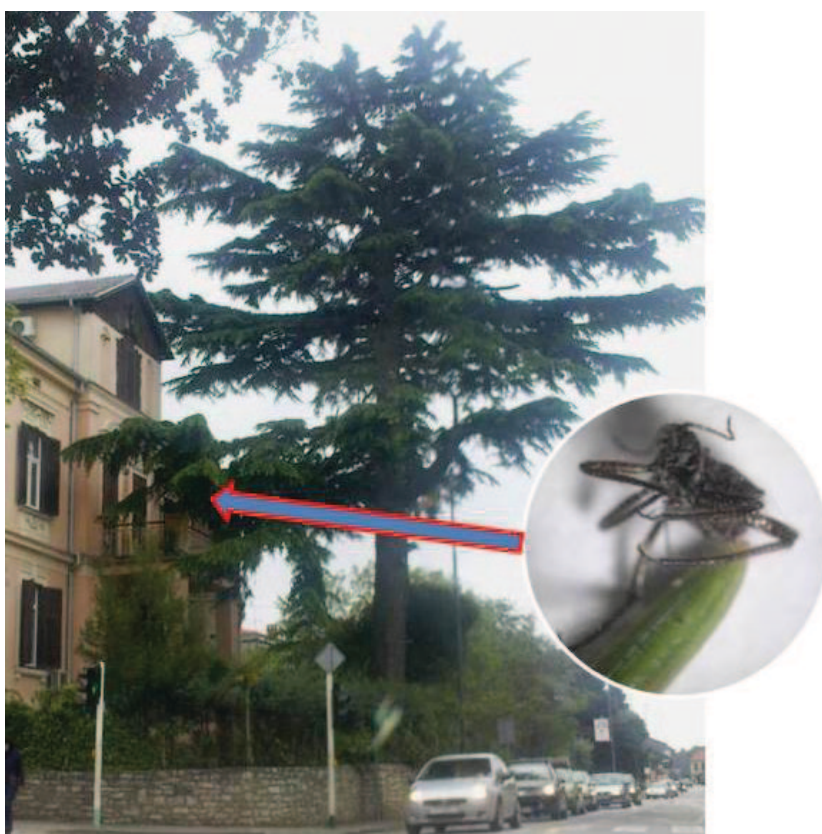

Slika 3. Lokacija nalaza Cinara cedri 23. listopada 2012. godine Figure 3 Finding site of Cinara cedri on October 23 ${ }^{\text {rd }}, 2012$. 
a)

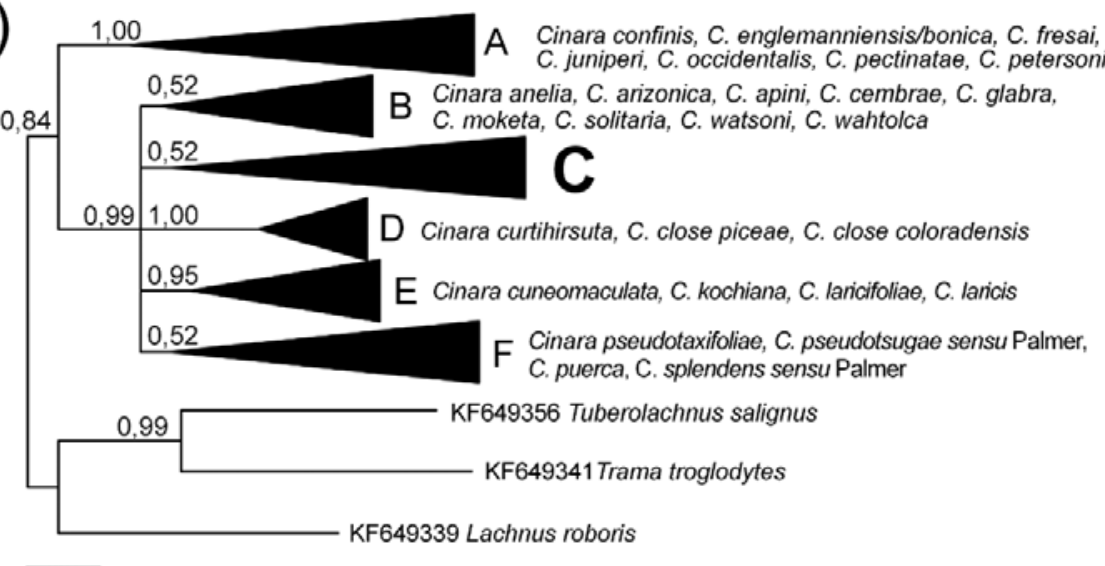

$\overline{0,03}$

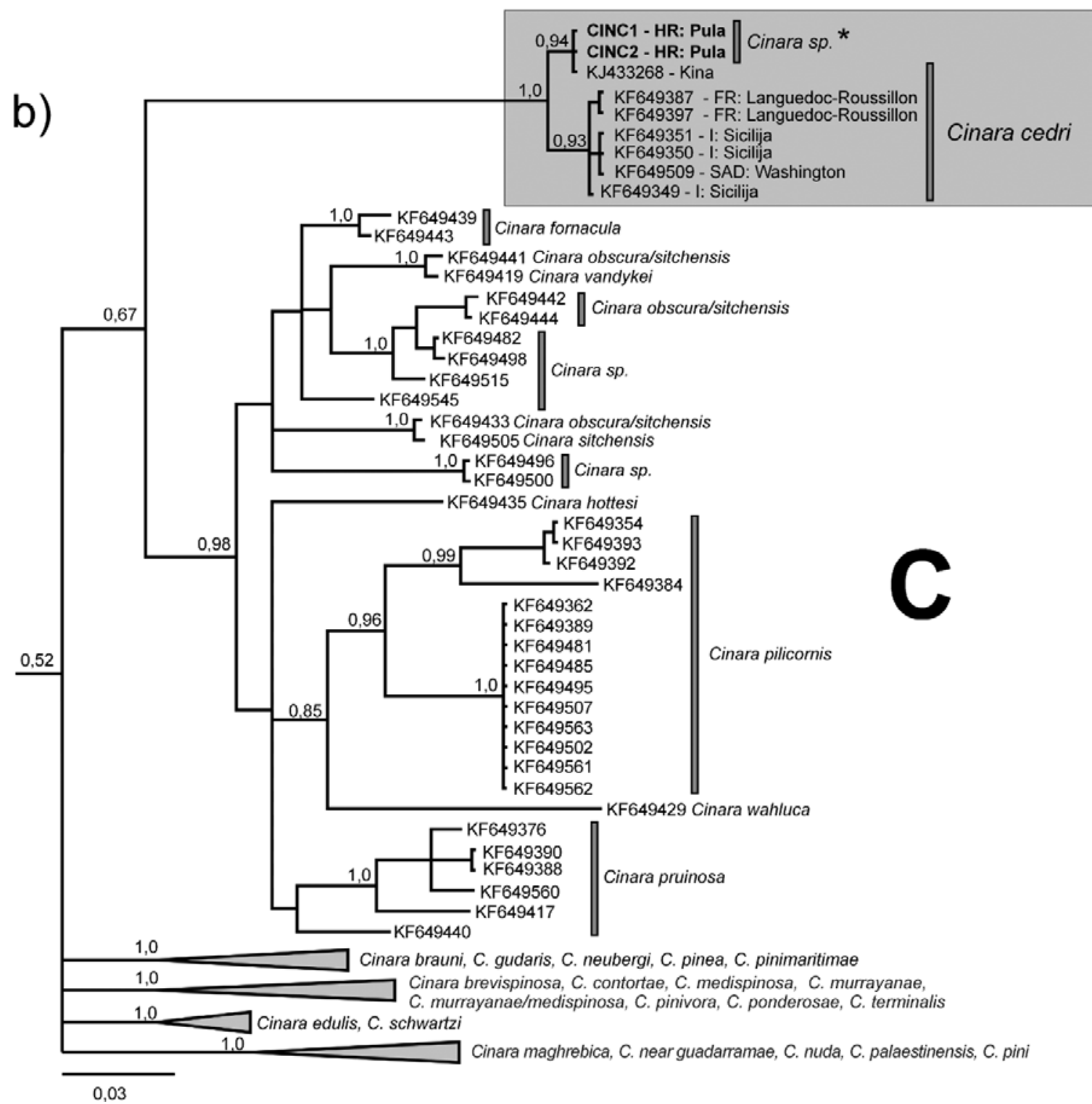

Slika 4. a) Topologija filogenetskog stabla konstruiranog Bayesian metodom na na temelju sekvenci mitohondrijskog gena za COI (DNA barkod regija) vrsta roda Cinara. Glavne grupe su kolabirane i prikazane su samo vrste koje obuhvaćaju b) Detaljniji prikaz grupe C koja sadrži haplotipove uzoraka Cinara sp. iz Pule $\left({ }^{*}\right)$. Brojevi na čvorovima predstavljaju podršku u obliku posteriornih vjerojatnosti (BPP). I = Italija, FR = Francuska, SAD $=$ Sjedinjene Američke Države

Figure 4 a) Topology of phylogenetic tree obtained by Bayesian inference based on mitochondrial COl sequences (DNA barcode region) of the Cinara species. Major clades are collapsed and all species clustered within each of them are depicted. b) Partially expanded clade $\mathrm{C}$ comprising haplotypes of Cinara sp. samples from Pula $\left(^{*}\right)$. Numbers at nodes represent Bayesian posterior probability (BPP) support. I = Italy, FR =France, SAD $=$ United States of America 
Ako uzmemo u obzir prisutnost u susjednim zemljama kao što su Italija, Mađarska, Srbija i Crna Gora (Aytar i dr. 2006), sa sličnim klimatskim prilikama, realno je očekivati pojavnost ove vrste i u drugim dijelovima Hrvatske. Kako se u zemljama u kojima je prisutna ne bilježe velike štete (Binazzi i dr. 2015) za očekivati je se da ni u Hrvatskoj njena prisutnost neće imati veliki utjecaj na zasađene populacije cedra. Teško je pretpostaviti kada je vrsta C. cedri došla u Hrvatsku, jer se tek kod njene masovnije pojavnosti može lako detektirati. Smatra se da se u prosjeku 3 - 5 godina nakon unosa nove vrste u Hrvatsku ona i otkrije (Matošević i Pajač Živković 2013).

U uzorku sa mjesta prvog nalaza (29. 10. 2015.) nisu pronađeni tragovi C. cedri, ali su pronađeni ostaci harlekinske božje ovčice, $H$. axyridis, invazivne vrste božje ovčice koja se posljednjih godina raširila na području Hrvatske, a poznata je kao izvrstan predator biljnih ušiju (Mičetić Stanković i dr. 2011). Kako su populacije harlekinske božje ovčice, $H$. axyridis, na području Istarske županije zadnjih godina u porastu (Landeka i dr. 2016) izvjestan je i njen predatorski utjecaj na populaciju C. cedri. Takav utjecaj je već opisan na srodnu alohtonu vrstu C. curvipes na području Turske (Görür i dr. 2015).

Precizna determinacija lisnih uši na temelju morfoloških značajki izuzetno je zahtjevna, jer je otežava vrlo velika morfološka sličnost brojnih vrsta, kao i visok unutarvrsni varijabilitet (Coeur d'acier i dr. 2014). S druge strane, molekularna metodologija „DNA barkodiranja“ (Hebert i dr. 2003) pokazala se kao izuzetno koristan alat za determinaciju morfološki sličnih europskih vrsta porodice Aphididae (Coeur d'acier i dr. 2014). Genetičke udaljenosti, kao i rezultati filogenetske analize te identifikacija putem BOLD platforme snažno podržavaju morfološku identifikaciju nepoznatih uzoraka iz Pule kao vrstu C. cedri. Grupiranje s ostalim uzorcima te vrste izvrsno je podržano u filogenetskom stablu, a genetičke udaljenosti od 0,0 - 1,6\% nalaze se unutar raspona intraspecifičnih genetičkih udaljenosti zabilježenih u studiji DNA barkodiranja europskih afida (Coeur d’acier i dr. 2014). Ipak, treba naglasiti da je zabilježeno preklapanje u vrijednostima intra- i interspecifičnih genetičkih udaljenosti, kako unutar europskih afida (Coeur d'acier i dr. 2014), tako i za neke vrste roda Cinara analizirane u radu od Jousselin i dr. (2013). Iako interspecifične genetičke udaljenosti u tom istraživanju uglavnom premašuju iznos od $2 \%$, te time i maksimalnu genetičku udaljenost uočenu između uzorka iz Pule i ostalih jedinki vrste C. cedri, genetičke udaljenosti između pojedinih parova distinktnih vrsta roda Cinara su manje, primjerice, C. anelia i C. moketa $(0,0-1,1 \%)$, C. anelia i C. wahtolca $(1,4-1,5 \%)$, C. moketa i C. wahtolca (0,8-1,5\%), C. apini i C. moketa $(0,2-1,5 \%)$, C. contortae i C. medispinosa (0,0 - 0,2 \%), C. contorate i C. murrayanae $(0,0-2,8)$, no prema autorima, u većini tih slučajeva se vrlo vjerojatno radi o pogrešnoj identifikaciji uzorka.
Veće genetičke udaljenosti između uzoraka iz Pule i kineskog uzorka s jedne strane, te uzoraka C. cedri iz Francuske, Sicilije i SAD-a s druge (dvije podgrupe unutar C. cedri grupe, Slika 4b), u odnosu na male genetičke udaljenosti unutar podgrupa, može se objasniti postojanjem dvije filogeografske linije iste vrste. Ipak, mogućnost da te dvije linije predstavljaju kompleks kriptičnih vrsta, ne može se u potpunosti odbaciti.

Uz ovu vrstu, i slične vrste Aphididae kao što su C. laportei i C. curvipes, s obzirom na klimatske uvjete zemalja u kojima je do sada zabilježena i prisutnost biljke domaćina možemo očekivati u Hrvatskoj. Razlog tome su trgovina sadnicama ukrasnog drveća uslijed širenja tržišta i opće globalizacije, kao i mogućnost prijenosa vjetrom (Coeur d’acier i dr. 2010). Prisutnost u susjednim zemljama vrste C. curvipes predstavlja dodatni rizik od ulaska, jer možemo očekivati unos iz Slovenije, Mađarske i Srbije (Hałaj i dr. 2015). Cinara curvipes bira više vrsta domaćina, pa osim cedrova napada i više vrsta jele (Abies grandis, Abies concolor, Abies koreana i Abies alba), smreki (Picea omorica, Picea pungens) i kanadsku čugu (Tsuga canadensis) (Jurc i dr. 2009), pa je time i njena prisutnost od većeg značenja.

Iz istraživanja je razvidno da se kod nas mogu sresti i nove vrste iz porodice Aphididae. Uz C. cedri moguć je ulaz i još nekih sličnih vrsta koje zbog prelaska na druge biljke domaćine mogu imati i značajni učinak na njih. Stoga je ubuduće potrebno obratiti veću pozornost na ovu, kod nas malo istraživanu skupinu kukaca.

\section{LITERATURA}

\section{REFERENCES}

- Aytar, F., 2006: Geographical distribution of Cinara cedri, Cinara (Cedrobium) laportei (Homo.; Aphididae) and newly discovered a parasitoid of Cinara cedri, Pauesia (Pauesia) anatolica (Hym.; Braconidae) in Turkey. VIII. European Congress of Entomology, on September 17-22, Supplementary Abstract Book-2, PVPP-77 (Poster Number) Poster Presentation, p.27, Izmir, Turkey

- Binazzi, F., Sabbatini, Peverieri, G., Roversi, P., 2015: First record in Cyprus of Cinara (cinara) cedri Mimeur (Aphididae Lachninae) on Cedrus brevifolia (Hooker fil.) Henry, Redia J Zool, 98: 151-154.

- Blackman, R. L. and V. F. Eastop. 2006. Aphids on the world's herbaceous plants and shrubs. 2 Vols. John Wiley \& Sons Ltd., England. 1439 pp.Coeur d'acier A, Pérez Hidalgo, N., PetrovićObradović, O., 2010: Aphids (Hemiptera, Aphididae) Chapter 9.2. Alien terrestrial arthropods of Europe, BioRisk, 4: 435-474.

- Coeur d'acier, A., Cruaud, A., Artige, E., Genson, G., Clamens, A-L., Pierre, E., Hudaverdian, S., Simon, J-C., Jousselin, E., Rasplus J-Y., 2014: DNA Barcoding and the Associated PhylAphidB@se Website for the Identification of European Aphids (Insecta: Hemiptera: Aphididae), Plos One, 9 (6), e97620.

- Fabre, J.P., 1976: Sur la présence en France de Cinara cedri (Mimeur) puceron nuisible au cédre, Comptes-Rendus de l' Académie d’Agriculture de France Juin 1976: 771-775. 
- Fabre, J.P., Chalon, A., Chizky, J., E. Robert, E., 1988: Possibilit es d'infestation par les pucerons: Cedrobium laportei Remaudi ere, Cinara cedri Mimeur (Homoptera, Lachnidae), chez le genre Cedrus, Ann Sci For, 45(2): 125-140.

- Folmer, O., Black, M., Hoeh, W., Lutz, R., Vrijenhoek, R., 1994: DNA primers for amplification of mitochondrial cytochrome c oxidase subunit I from diverse metazoan invertebrates, Mol Mar Biol Biotechnol, 3: 294-299.

- Görür, G., Toper, Kaygin, A., Şenol, Ö., Akyildirim Beğen, H., 2015: Cinara curvipes (Patch, 1912) (Hemiptera; Aphididae) as new aphid species for Turkish aphidofauna, Artvin Coruh University Journal of Forestry Faculty, 16 (41): 37-39.

- Hałaj, R., Osiadacz, B., 2015: On foreign land: the conquest of Europe by Cinara curvipes (Patch, 1912), Deutsche Entomologische Zeitschrift 62(2): 261-265

- Hall, T.A., 1999: BioEdit: a user-friendly biological sequence alignment editor and analysis program for Windows 96/98/NT, Nucleic Acids Symp Ser, 41: 95-98.

- Hebert, P.D.N., Cywinska, A., Ball, S.L., deWaard, J.R., 2003: Biological identifications through DNA barcodes, Proc R Soc Lond B Biol Sci, 270: 313-321.

- Jousselin, E., Cruaud, A., Genson, G., 2013: Is ecological speciation a major trend in aphids? Insights from a molecular phylogeny of the conifer feeding genus Cinara, Front Zool,10: 1-18.

- Jurc, M., Poljaković-Pajnik, L., Jurc, D., 2009: The first record of Cinara curvipes (patch, 1912) (Homoptera, Aphididae) in Slovenia and its possible economic impact, Zbornik gozdarstva in lesarstva, 88: $21-29$.

- Landeka N., Kokan B., Žitko T., Šušnić V., Klobučar, A.2016: Masovne pojave azijske božje ovčice, Harmonia axyridis (Pal- las, 1773) tijekom 2015. godine u Hrvatskoj i javnozdravstveni značaj, Zbornik radova DDD i ZUPP 2016, 28. Seminar „Novine u djelatnosti dezinfekcije, dezinsekcije i deratizacije i zaštite uskladištenih poljoprivrednih proizvoda, Korunić, 171179.15.Matošević, D., Pajač Živković, I., 2013: Strane fitofagne vrste kukaca i grinja na drvenastom bilju u Hrvatskoj, Šumarski list, 3-4: 191-205.

- Mičetić Stanković, V., Koren, T., Stanković, I., 2011: The Harlequin ladybird continues to invade southeastern Europe, Biol Invasions, 13 (8): 1711-1716.

- Poljaković-Pajnik, L., Petrović-Obradović, O. 2002: Bowlegged fir aphid Cinara curvipes (patch) (Aphididae, Homoptera) new pest of Abies concolor Serbia, Acta Ent Serb, 7 (1/2): 147-150.

- Posada, D., 2008: jModelTest: Phylogenetic Model Averaging, Mol Biol Evol, 25: 1253-1256.

- Ronquist, F., Huelsenbeck, J.P., 2003: MrBayes 3: Bayesian phylogenetic inference under mixed models, Bioinformatics, 19: 1572-1574.

- Scheurer, S., Binazzi, A., 2004: Notes in bio-ecology and ethology of Cinara curvipes (Patch), a newly introduced species into Europe (Aphididae, Lachninae), Redia, 87: 61-65.

- Tamura, K., Stecher, G., Peterson, D., Filipski, A., Kumar, S., 2013: MEGA6: Molecular Evolutionary Genetics Analysis version 6.0. Mol Biol Evol, 30: 2725-2729.

- Yu, G.Y., Wang, H., 2014: First record of Cinara cedri Mimeur (Hemiptera, Aphididae, Lachninae) on Cedrus deodara in Beijing, China, Natural Enemies of Insects, 2: 260-264.

\section{Summary}

Aphid species Cinara cedri (Mimeur, 1936), the unusual species of the Croatian aphid fauna, was recorded in the area of Pula (Istria, Croatia) on October $23^{\text {rd }}, 2012$ (Figure 2,3). It was found in the southern part of the town on Cedrus libani tree. The species was identified by combined morphological and molecular approaches. Standardised fragment of the mitochondrial cytochrome c oxidase I gene (DNA barcode region) was used as a molecular marker. Molecular analysis supported morphological identification of specimens as Cinara cedri. Phylogenetic analysis placed Pula specimens within highly supported, monophyletic Cinara cedri clade. In the overlaping region (629 bp) their sequences are identical to the sequence of Cinara cedri from China, while the pairwise genetic distance between them and 56 other Cinara species included in analysis were greater than 7.7 \% (Figure 4 b). Identification through Barcode of Life Data Systems (BOLD) web platform (currently containing DNA barcode sequences of 99 species of genus Cinara), matched Pula specimens to Cinara cedri with $99.7 \%$ probability of placement.

Monitoring conducted during the time period of 2013 - 2015 in the wider area has not revealed either new populations of this species or the population increment at the original location.

KEY WORDS: Aphididae, Cinara cedri, Pula, Croatia, alien species, DNA barcoding 